Implementasi Model Pembelajaran....(Isnaini)

\title{
IMPLEMENTASI MODEL PEMBELAJARAN PAIRS-CHECKS UNTUK MENINGKATKAN HASIL BELAJAR IPA MATERI PERUBAHAN WUJUD BENDA
}

\author{
Oleh: Isnaini \\ (Guru SD Negeri 162 Palembang) \\ Email:isnaini@gmail.com
}

\begin{abstract}
Abstrak
Hasil pengamatan penulis sebagian guru di kelas V.a SD Negeri 162 Palembang bahwa Hasil Belajar IPA Materi pengaruh kalor terhadap perubahan suhu dan wujud bendapeserta didik SD Negeri 162 Palembang masih di bawah kriteria ketuntasan minimum (KKM) yang ditetapkan yaitu 65. Untuk itulah saya selaku guru kelas harus membimbing siswa agar memahami pembelajaran tersebut dapat dikuasai. Penelitian ini dilaksanakan pada bulan Februari sampai dengan April semester genap 2017/2018. Subyek penelitian adalah peserta didik kelas V.a SD Negeri 162 Palembang dengan jumlah 23 peserta didik, pada pokok bahasan menganalisis pengaruh kalor terhadap perubahan suhu dan wujud benda dalam kehidupan sehari hari. Dari hasil kegiatan pembelajaran yang telah dilakukan selama dua siklus, dan berdasarkan seluruh pembahasan serta analisis yang telah dilakukan dapat disimpulkan bahwa pembelajaran kooperatif strategi pembelajaran Pairs-Checks memiliki dampak positif dalam meningkatkan hasil belajar belajar peserta didik kelas V.a SDN 162 Palembang yang ditandai dengan peningkatan ketuntasan hasil belajar IPA Materi Pengaruh kalor terhadap perubahan suhu dan wujud benda peserta didik kelas V.a SD Negeri 162 Palembang dalam setiap siklus, yaitu pra siklus 52,17\%, siklus I sebesar $65,22 \%$ dan siklus II $86,96 \%$.
\end{abstract}

Kata Kunci: IPA, Pairs-Checks, Perubahan Wujud Benda

\section{IMPLEMENTATION OF PAIRS-CHECKS LEARNING MODELS TO IMPROVE MATERIAL LEARNING OUTCOMES OF MATERIAL CHANGES}

\begin{abstract}
The observations of the authors of some teachers in the Va. 162 Palembang Elementary School class that Science Learning Outcomes The material of heat influence on changes in the temperature and shape of objects of 162 Palembang elementary school students is still below the minimum completeness criterion (65). class must guide students to understand the learning can be mastered. This research was conducted from February to April even semester 2017/2018. The subjects of the study were class V.a students of 162 Palembang State Elementary School with a total of 23 students, on the subject of analyzing the effect of heat on changes in temperature and the appearance of objects in daily life. From the
\end{abstract}


results of the learning activities that have been carried out for two cycles, and based on all the discussions and analyzes that have been carried out it can be concluded that cooperative learning Pairs-Checks learning strategies have a positive impact on improving learning outcomes of class Va SDN 162 Palembang students characterized by increased completeness Science learning outcomes Material Effect of heat on changes in the temperature and shape of objects in class Va 162 Elementary School Palembang Palembang in each cycle, namely pre cycle $52.17 \%$, cycle I was $65.22 \%$ and cycle II was $86.96 \%$..

Keywords: Science, Pairs-Checks, Changes in the Shape of Objects

\section{A. PENDAHULUAN}

Pendidikan IPA di sekolah diharapkan dapat menjadi wahana bagi peserta didik untuk mempelajari diri sendiri dan alam sekitarnya, serta prospek pengembangan lebih lanjut dalam menerapkannya dalam kehidupan sehari-hari, yang didasarkan pada metode ilmiah. Pembelajaran IPA menekankan pada pengalaman langsung untuk mengembangkan kompetensi agar peserta didik mampu memahami alam sekitar melalui proses "mencari tahu" dan "berbuat". Hal ini akan membantu peserta didik untuk memperoleh pemahaman yang lebih mendalam.

Kenyataan di lapangan terjadi di SD Negeri 162 Palembang dalam proses pembelajaran peserta didik hanya menghafal konsep dan kurang mampu menggunakan konsep tersebut jika menemui masalah dalam kehidupan nyata yang berhubungan dengan konsep yang dimiliki. Hal ini dikaitkan dengan pembelajaran IPA di kelas V.a SD Negeri 162 Palembang materi pengaruh kalor terhadap perubahan suhu dan wujud benda peserta didik kurang mampu menentukan masalah dan merumuskannya. Padahal materi tersebut merupakan materi yang terkait kehidupan nyata peserta didik dalam aktivitas sehari-hari. Kalor merupakan salah satu bentuk energi, sehingga dapat berpindah dari satu sistem ke sistem yang lain karena adanya perbedaan suhu. Sebaliknya, setiap ada perbedaan suhu antara dua sistem maka akan terjadi perpindahan kalor. Sebagai contoh, es yang dimasukkan ke dalam gelas berisi air panas, maka es akan mencair dan air menjadi dingin. Karena ada perbedaan suhu antara es dan air 
maka air panas melepaskan sebagian kalornya sehingga suhunya turun dan es menerima kalor sehingga suhunya naik (mencair).

Fenomena yang terjadi pada kelas V.a SD Negeri 162 Palembang pada ulangan harian Tema 7 "Peristiwa dalam Kehidupan" dengan kompetensi dasar mengamati fenomena pengaruh kalor terhadap perubahan suhu dan wujud benda dan mengidentifikasi perubahan wujud benda materi bulan September 2017 sebanyak 52,17\% peserta didik nilainya mencapai KKM 65, dan 47,83\% peserta didik belum mencapai KKM. Hasil pengamatan penulis sebagai guru di kelas V.a SD Negeri 162 Palembang bahwa Hasil Belajar IPA Materi pengaruh kalor terhadap perubahan suhu dan wujud bendapeserta didik SD Negeri 162 Palembang masih di bawah kriteria ketuntasan minimum (KKM) yang ditetapkan yaitu 65.

Untuk itulah saya selaku guru kelas harus membimbing siswa agar memahami pembelajaran tersebut dapat dikuasai. Berbicara mengenai proses pembelajaran dan pengajaran yang tidak tepat terkadang membuat pemahaman peserta didik terhadap materi ajar kurang dapat diterima peserta didik .Walaupun demikian, kita menyadari bahwa ada peserta didik yang mampu menghafal materi yang diterimanya, namun kenyataanya mereka sering kurang memahami dan mengerti secara mendalam pengetahuan yang bersifat hafalan tersebut. Sehingga peserta didik kurang mampu menghubungkan antara apa yang mereka pelajari dengan bagaimana pengetahuan tersebut akan dimanfaatkan atau diaplikasikan (Trianto, 2010:7).

Berdasarkan uraian di atas, model pembelajaran yang dapat digunakan guru hendaknya dapat menghasilkan hasil belajar peserta didik yang lebih baik diantaranya adalah model pembelajaran kooperatif strategi pembelajaran PairsChecks, dalam pembelajaran IPA. Strategi pembelajaran Pairs-Checks ini dikembangkan oleh Spencer Kagan pada tahun 1990. Pada strategi ini siswa dilatih bekerja sama untuk mengerjakan soal-soal atau memecahkan masalah secara berpasangan, kemudian saling memeriksa/ mengecek pekerjaan atau pemecahan masalah masing-masing pasangannya. Untuk saling membantu dalam menguasai materi pelajaran guna mencapai hasil maksimal. 
Berdasarkan latar belakang yang dikemukakan di atas, maka yang menjadi permasalahan dalam penelitian ini adalah"bagaimana upaya meningkatkan Hasil Belajar IPA materi pengaruh kalor terhadap perubahan suhu dan wujud benda melalui penerapan model pembelajaran kooperatif strategi pembelajaran PairsChecks peserta didik Kelas V.a SD Negeri 162 Palembang?”.

Cooperatif learning merupakan strategi belajar dengan sejumlah peserta didik sebagai anggota kelompok kecil yang tingkat kemampuanya berbeda. dalam menyelesaikan tugas kelompoknya, setiap peserta didik anggota kelompok harus saling bekerja sama dan saling membantu untuk memahami materi pembelajaran (Isjoni, 2009:12).

Dalam belajar Cooperatif peserta didik belajar bersama sebagai suatu tim dalam menyelesaikan tugas-tugas kelompok untuk mencapai tujuan bersama. Jadi, setiap anggota kelompok memiliki tanggung jawab yang sama untuk keberhasilan kelompoknya. Belajar kooperatif muncul dari konsep bahwa peserta didik akan lebih mudah menemukan dan memahami konsep yang sulit jika mereka saling berdiskusi dengan temannya (Trianto, 2010:56). Peserta didik secara rutin bekerja dalam kelompok untuk saling membantu memecahkan masalah-masalah yang kompleks. Jadi hakikat sosial dan penggunaan kelompok sejawat menjadi aspek utama dalam belajar kooperatif. Menurut Johnson dan Johnson (dalam Trianto, 2010:57) menyatakan bahwa tujuan pokok belajar kooperatif adalah memaksimalkan belajar peserta didik untuk peningkatan hasil akademik dan pemahaman baik secara individu maupun secara kelompok.

Menurut Zamroni (dalam Trianto, 2010:57) mengemukakan bahwa manfaat penerapan belajar kooperatif adalah dapat mengurangi kesenjangan pendidikan khususnya dalam wujud input pada level individual. Disamping itu, belajar kooperatif dapat mengembangkan solidaritas dikalangan peserta didik . Dengan belajar kooperatif, diharapkan kelak akan muncul generasi baru yang memiliki hasil akademik yang cemerlang dan memiliki solidaritas sosial yang kuat.

Para ahli telah menunjukkan bahwa pembelajaran kooperatif dapat meningkatkan kinerja peserta didik dalam tugas-tugas akademik, unggul dalam membantu peserta didik memahami konsep-konsep yang sulit, dan membantu 
Implementasi Model Pembelajaran....(Isnaini)

peserta didik menumbuhkan kemampuan berpikir kritis. Pembelajaran kooperatif memberikan peluang kepada peserta didik yang berbeda latar belakang dan kondisi untuk bekerja saling bergantung satu sama lain atas tugas-tugas bersama, dan melalui penggunaan struktur penghargaan kooperatif, belajar untuk menghargai satu sama lain.

Strategi pembelajaran Pairs-Checks (Berpasangan dan Saling Memeriksa) adalah salah satu strategi pembelajaran berpasangan selain Think-PairsShare (TPS) dan Think-Pairs-Write (Berpikir-Berpasangan-Menulis) pada model pembelajaran kooperatif. Strategi Pairs-Checks ini dikembangkan oleh Spencer Kagan pada tahun 1990. Pada strategi ini siswa dilatih bekerja sama untuk mengerjakan soal-soal atau memecahkan masalah secara berpasangan, kemudian saling memeriksa/mengecek pekerjaan atau pemecahan masalah masing-masing pasangannya.

Dalam kegiatan belajar mengajar bahwa hasil belajar yang belajar yang dicapai oleh seorang tergantung dari kemampuan baik yang berupa bakat, minat dan kecerdasan. Seoarang peserta didik yang berkemampun tinggi cenderung untuk dapat memperoleh harus belajar yang tinggi dan sebaliknya yang berkemampuan rendah cenderungan untuk mendapatkan hasil belajar yang rendah. Nasution mendefinisikan hasil belajar yang sebagai berikut :

Pembelajaran merupakan suatu proses penyampaian pengetahuan, yang dilaksanakan dengan menuangkan pengetahuan kepada siswa(Oemar Hamalik, 2008:25). Bila pembelajaran dipandang sebagai suatu proses, maka pembelajaran merupakan rangkaian upaya atau kegiatan guru dalam rangka membuat siswa belajar.

Proses tersebut dimulai dari merencanakan progam pengajaran tahunan, semester dan penyusunan persiapan mengajar (lesson plan) berikut persiapan perangkat kelengkapannya antara lain berupa alat peraga dan alat-alat evaluasinya (Zaini, 2004:4). IPA berhubungan dengan cara mencari tahu tentang alam secara sistematis, sehingga IPA bukan hanya penguasaan kumpulan sistematis dan IPA bukan hanya penguasaan kumpulan pengetahuan yang berupa fakta-fakta, konsep- 
konsep atau prinsip-prinsip saja, tetapi juga merupakan suatu proses penemuan (Sulistyorini, 2007:39).

Menurut Iskandar IPA adalah ilmu yang mempelajari peristiwa-peristiwa yang terjadi alam (Iskandar, 2001:2). Ilmu Pengetahuan Alam merupakan mata pelajaran di SD yang dimaksudkan agar siswa mempunyai pengetahuan, gagasan dan konsep yang terorganisasi tentang alam sekitar, yang diperoleh dari pengalaman melalui serangkaian proses ilmiah antara lain penyelidikan, penyusunan dan penyajian gagasan-gagasan. Pada prinsipnya, mempelajari IPA sebagai cara mencari tahu dan cara mengerjakan atau melakukan dan membantu siswa untuk memahami alam sekitar secara lebih mendalam (Depdiknas dalam Suyitno, 2002:7).

\section{B. METODOLOGI PENELITIAN}

Sesuai dengan permasalahan dan tujuan penelitian, maka jenis penelitian ini adalah penelitian tindakan kelas (PTK). Penelitian tindakan kelas merupakan bentuk penelitian yang dilaksanakan secara langsung oleh guru dalam praktek pembelajaran, dimana guru (peneliti) mengadakan tindakan tertentu berdasarkan masalah-masalah penting di lapangan yang harus segera diatasi (Arikunto, 2014).

Tempat penelitian adalah tempat yang digunakan dalam melakukan penelitian untuk memperoleh data yang diinginkan. Penelitian ini bertempat di SD Negeri 162 Palembang yang terletak di Jalan R. Sukamto Lr. Rawa Bening Palembang. Waktu penelitian adalah waktu berlangsungnya penelitian atau saat penelitian ini dilangsungkan. Penelitian ini dilaksanakan pada bulan Februari sampai dengan April semester genap 2017/2018. Subjek penelitian adalah peserta didik kelas V.a SD Negeri 162 Palembang dengan jumlah 23 peserta didik, pada pokok bahasan menganalisis pengaruhkalor terhadap perubahan suhu dan wujud benda dalam kehidupan sehari hari. Ditambah satu orang guru sebagai kolaborator yang mengamati jalannya kegiatan pembelajaran bernama Aisyah, S.Pd.

Indikator keberhasilan penelitian tindakan kelas ini adalah secara keseluruhan siswa tidak mengalami kesulitan dalam menyelesaikan soal tes yang diberikan pada setiap akhir tindakan. Hal ini ditunjukan dengan hasil subyek 
Implementasi Model Pembelajaran ....(Isnaini)

memperoleh persentase di atas $\mathrm{KKM} \geq 65$ dan sebanyak $\geq 85 \%$ secara klasikal peserta didik tuntas belajar IPA.

Sesuai dengan jenis penelitian yang dipilih yaitu penelitian tindakan, maka penelitian ini menggunakan model penelitian tindakan dari Kemmis dan Taggart (dalam Arikunto, 2002:83), yaitu berbentuk spiral dari siklus yang satu ke siklus yang berikutnya. Setiap siklus meliputi planning (rencana), action (tindakan), observasi (pengamatan) dan reflection (refleksi). Langkah pada siklus berikutnya adalah perencanaan yang sudah direvisi, tindakan, pengamatan dan refleksi. Sebelum masuk pada siklus I dilakukan tindakan pendahuluan yang berupa identifikasi permasalahan

\section{HASIL PENELITIAN DAN PEMBAHASAN}

Tabel 1 Rekapitulasi Hasil Tes Formatif Pada Pra Siklus

\begin{tabular}{|c|l|c|}
\hline No. & \multicolumn{1}{|c|}{ Uraian } & Pra Siklus \\
\hline 1. & Nilai rata-rata tes formatif & 62,83 \\
\hline 2. & Jumlah siswa yang tuntas belajar & 12 \\
\hline 3. & Jumlah siswa yang belum tuntas & 11 \\
\hline 4. & Persentase ketuntasan belajar & 52,17 \\
\hline 5. & Persentase belum tuntas belajar & 47,83 \\
\hline
\end{tabular}

Berdasarkan tabel di atas diketahui bahwa rata - rata tes formatif untuk mata pelajaran IPA siswa kelas V.a SD Negeri 162 Palembang pada kondisi awal /Pra siklus pembelajaran adalah sebesar 62,83. Dan ketuntasan belajar kelas V.a hanya sebesar 52,17\% atau 12 orang siswa yang tuntas. Hal ini berarti, jika di lihat dari segi kriteria ketuntasan minimal belajar mata pelajaran IPA sebesar 65 artinya secara keseluruhan siswa kelas V.a SD Negeri 162 Palembang belum tuntas.

Berdasarkan hasil diskusi kecil dengan teman sejawat bernama ibu Aisyah, S.Pd yang selaku kolaborator SD Negeri 162 Palembang maka ditentukanlah model pembelajaran model kooperatif strategi pembelajaran Pairs-Checks yang akan digunakan dalam proses tindakan perbaikan pembelajaran IPA yang diharapkan dapat meningkatkan hasil belajar IPA Materi Pengaruh kalor terhadap 
perubahan suhu dan wujud benda yang pelaksanaannya akan dilaksanakan dalam 2 siklus.

\section{Siklus I}

Berikutnya adalah rekapitulasi hasil tes formatif peserta didik seperti terlihat pada tabel berikut.

Tabel 2 Rekapitulasi Hasil Tes Formatif Pada Siklus I

\begin{tabular}{|c|l|c|}
\hline No. & \multicolumn{1}{|c|}{ Uraian } & Siklus I \\
\hline 1. & Nilai rata-rata tes formatif & 66,96 \\
\hline 2. & Jumlah siswa yang tuntas belajar & 15 \\
\hline 3. & Jumlah siswa yang belum tuntas & 18 \\
\hline 4. & Persentase ketuntasan belajar & 65,22 \\
\hline 5. & Persentase belum tuntas belajar & 34,78 \\
\hline
\end{tabular}

Dari tabel di atas dapat dijelaskan bahwa dengan menerapkan model kooperatif strategi pembelajaran Pairs-Checks diperoleh nilai rata-rata hasil belajar peserta didik adalah 66,96 dan ketuntasan belajar mencapai 65,22\% atau ada 15 peserta didik dari 23 peserta didik sudah tuntas belajar. Hasil tersebut menunjukkan bahwa pada siklus pertama secara klasikal peserta didik belum tuntas belajar, karena peserta didik yang memperoleh nilai $\geq 65$ hanya sebesar $65,22 \%$ lebih kecil dari persentase ketuntasan yang dikehendaki yaitu sebesar $85 \%$.

\section{Siklus II}

Berikutnya adalah rekapitulasi hasil tes formatif peserta didik seperti terlihat pada tabel berikut:

Tabel 3 Rekapitulasi Hasil Tes Formatif Pada Siklus II

\begin{tabular}{|c|l|c|}
\hline No. & \multicolumn{1}{|c|}{ Uraian } & Siklus II \\
\hline 1. & Nilai rata-rata tes formatif & 72,17 \\
\hline 2. & Jumlah siswa yang tuntas belajar & 20 \\
\hline 3. & Jumlah siswa yang belum tuntas & 3 \\
\hline 4. & Persentase ketuntasan belajar & 86,96 \\
\hline 5. & Persentase belum tuntas belajar & 13,04 \\
\hline
\end{tabular}

Berdasarkan tabel diatas diperoleh nilai rata-rata tes formatif sebesar 72,17 dan dikarenakan 20 atau 86,96\% peserta didik telah mencapai ketuntasan belajar. Maka secara klasikal ketuntasan belajar yang telah tercapai sebesar 86,96\% 
(termasuk kategori tuntas). Hasil pada siklus II ini mengalami peningkatan lebih baik dari siklus I. Adanya peningkatan hasil belajar pada siklus II ini dipengaruhi oleh adanya peningkatan kemampuan guru dalam menerapkan pembelajaran dengan model kooperatif strategi pembelajaran Pairs-Checks sehingga peserta didik menjadi lebih terbiasa dengan pembelajaran seperti ini sehingga peserta didik lebih mudah dalam memahami materi yang telah diberikan. Pada siklus II ini ketuntasan secara klasikal telah tercapai, sehingga penelitian ini hanya sampai pada siklus II.

Pada siklus II guru telah menerapkan pembelajaran dengan model kooperatif strategi pembelajaran Pairs-Checks dengan baik dan dilihat dari aktivitas peserta didik serta hasil belajar peserta didik pelaksanaan proses belajar mengajar sudah berjalan dengan baik. Maka tidak diperlukan revisi terlalu banyak, tetapi yang perlu diperhatikan untuk tindakan selanjutnya adalah memaksimalkan dan mepertahankan apa yang telah ada dengan tujuan agar pada pelaksanaan proses belajar mengajar selanjutnya penerapan pembelajaran dengan model kooperatif strategi pembelajaran Pairs-Checks dapat meningkatkan proses belajar mengajar sehingga tujuan pembelajaran dapat tercapai.

\section{PEMBAHASAN}

Melalui hasil peneilitian ini menunjukkan bahwa pembelajaran dengan model kooperatif strategi pembelajaran Pairs-Checks memiliki dampak positif dalam meningkatkan hasil belajar peserta didik. Ditandai dengan kemampuan mereka dalam menjawab pertanyaan yang di berikan kelompok peserta didik lainnya dalam pembelajaran. peserta didik mampu menjawab bagian akar tumbuhan dan fungsinya, mampu menjawab bagian batang tumbuhan, daunbagian bunga dan fungsinya. Dilihat dari ketuntasan belajar materi menganalisis pengaruhkalor terhadap perubahan suhu dan wujud benda dalam kehidupan sehari hari ketuntasan belajar meningkat dari pra siklus, siklus I dan II) yaitu masing-masing 52,17\%, 65,22\% dan 86,96\%. Pada siklus II ketuntasan belajar peserta didik secara klasikal telah tercapai. 


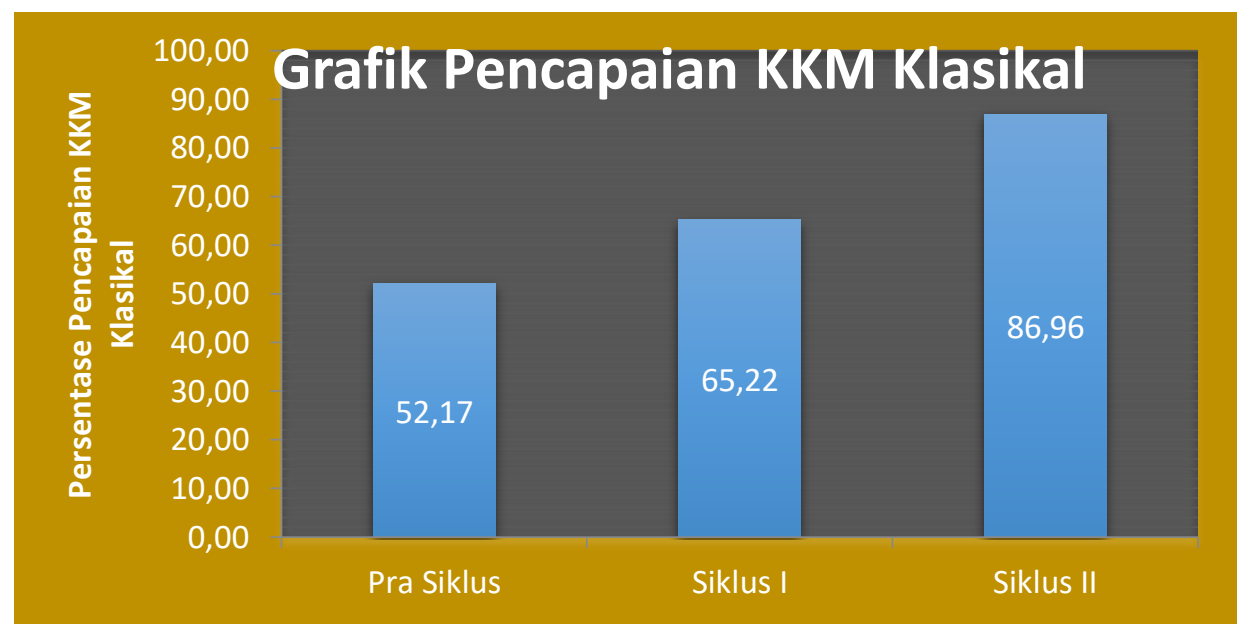

Gambar 1 Pencapaian KKM Klasikal

\section{SIMPULAN}

Dari hasil kegiatan pembelajaran yang telah dilakukan selama dua siklus, dan berdasarkan seluruh pembahasan serta analisis yang telah dilakukan dapat disimpulkan bahwa pembelajarankooperatif strategi pembelajaran Pairs-Checks memiliki dampak positif dalam meningkatkan hasil belajar belajar peserta didik kelas V.a SDN 162 Palembang yang ditandai dengan peningkatan ketuntasan hasil belajar ipa Materi Pengaruh kalor terhadap perubahan suhu dan wujud benda peserta didik kelas V.a SD Negeri 162 Palembang dalam setiap siklus, yaitu pra siklus $52,17 \%$, siklus I sebesar $65,22 \%$ dan siklus II 86,96\%.

Perencanaan pembelajaran yang dibuat oleh guru sebaiknya disusun sesuai dengan tuntutan kurikulum, dengan memperhatikan aspek-aspek diantaranya : a) aspek kurikulum, b) bahan pembelajaran, c) strategi pembelajaran, d) media dan sumber belajar, e) evaluasi, sehingga tujuan pembelajaran yang diharapkan dapat tercapai. Kepada Kepala Sekolah hendaknya mensosialisasikan hasil penelitian ini, dan membantu sarana atau fasilitas untuk belajar dan menerapkan model pembelajaran kooperatif strategi pembelajaran Pairs-Checks. 


\section{DAFTAR PUSTAKA}

Arikunto, S. (2014). Penelitian Tindakan Kelas. Jakarta: PT Bumi Aksara.

Isjoni. (2009). Cooperative Learning: Mengembangkan Kemampuan Belajar Kelompok. Bandung: Alfabeta.

Iskandar. (2001). Pendidikan Ilmu Pengetahuan Alam. Bandung: Maulana.

Hamalik, Oemar. (2008). Proses Belajar Mengajar. Jakarta: Bumi Aksara.

Spencer, Kagan. (1990). Strategi Pairs - Checks. http://educationstudentsmart. blogspot.com/2012/03/model-pembelajaran-pair-check.html) diakses 24 Maret 2018

Sulistyorini, Sri. (2007). Model Pembelajaran IPA Sekolah Dasar dan Penerapannya dalam KTSP. Yogyakarta: Media Group.

Suyitno. (2002). Petunjuk Praktis Penelitian Tindakan Kelas. Semarang.

Trianto. (2010). Mendesain Model Pembelajaran Inovatif-Progesif. Jakarta: Kencana Prenada Media Group.

Zaini, Hisyam. (2004). Strategi Pembelajaran Aktif. Yogyakarta: Pustaka Insane Madani. 